УДК 342.9

DOI https: / / doi.org/10.32837 / yuv.v0i4.1000

\author{
А. Подольська,
}

аспірант кафедри адміністративного та фінансового права

Національного Університету «Одеська юридична академія»

\title{
ІМПЛЕМЕНТАЦІЯ МІЖНАРОДНИХ СТАНДАРТІВ ПОДАТКОВОГО КОНТРОЛЮ В УКРАЇНСЬКЕ ЗАКОНОДАВСТВО
}

\begin{abstract}
Формування ефективного механізму оподаткування та податкового контролю $є$ запорукою стабільного економічного розвитку держави. Піклуючись про своїх громадян держава приймає заходи щодо зменшення податкового навантаження. Законодавчо встановленні норми, що стосуються можливості зменшення розміру ставок податків, звільнення від оподаткування в встановлених законом випадках, а також уникнення подвійного оподаткування.
\end{abstract}

Подвійне оподаткування, являє собою багаторазове стягнення одного і того ж податку з певного платника. Його прийнято розділяти на внутрішнє та зовнішнє подвійне оподаткування. Зовнішнє подвійне оподаткування, як складова явища подвійного оподаткування, виникає в результаті колізії податкових розпоряджень двох чи більше держав. В основу визначення поняття „міжнародне подвійне оподаткування" споконвічно було закладене твердження, що міжнародне подвійне оподаткування виникає, коли дві автономні податкові влади (зокрема, дві держави) одночасно обкладають однорідним податком того самого платника. Проблема подвійного оподаткування, як зазначає проф. Т.А. Латковська, перебуває на своєрідному стику категорій об’єкта оподаткування та платника, тобто це випадки, коли вони оподатковується в межах однієї або декількох фіскальних юрисдикцій податком певного виду більше, ніж один раз [5].

Ще в першій половині минулого століття Ліга націй задалась питанням вирішення даної проблеми. В підсумку були запропоновані рекомендації щодо укладання міжнародних податкових угод 3 метою уникнення подвійного оподаткування доходів і майна транснаціональних компаній. В подальшому питання розглядалось комітетами ОOH та іншими міжнародними організаціями, включаючи Організацію економічної співпраці та розвитку (ОЕСР). У результаті були створені та опубліковані «Типова конвенція про усунення подвійного оподаткування доходів i капіталу» (1963р.), яка в подальшому змінювалась та доповнювалась підлаштовуючись під нові економічні та правові реалії (остання редакція 2017 p.), «Типова конвенція ООН про усунення подвійного оподаткування доходів і капіталу» (1980p.), «Типовий договір США про уникнення подвійного оподаткування».

На основі трьох вище наведених моделей Міністерством фінансів України був створений проект Конвенції про уникнення подвійного оподаткування доходів та майна та запобігання ухиленням від сплати податку. В свою чергу цей проект в подальшому використовувався при укладенні Україною більш ніж семидесяти угод в даній cфepi.

Вирішення однієї проблеми потягнуло за собою іншу, пов'язану з використання прогалин у взаємодії різних податкових систем та існування юрисдикцій низького оподаткування.

Одним зі способів зниження витрат, пов'язаних зі сплатою податків 
та збільшення розміру чистого прибутку, протягом тривалого часу був і залишається механізм ефективного застосування наявних у національному та міжнародному податковому законодавстві низьких податкових ставок, податкових пільг, податкових знижок, податкових кредитів, прогалин, колізій у процесі здійснення податкового планування під час організації корпоративної структури та господарської діяльності суб'єктів господарювання 3 метою зменшення бази оподаткування й виведення прибутку з-під оподаткування [4]. В подальшому такі дії призвели до розмиванням бази оподаткування і переміщенням прибутків за кордон та утворили поняття агресивного податкового планування.

В липні 2013 року з метою гармонізації та підвищення ефективності співпраці в сфері контролю за оподаткуванням транснаціональних компаній шляхом виключення або мінімізаціï юридичних прогалин, G-20 разом з ОЕСР приймають новий план дій, що отримує назву «План протидіï практикам розмивання оподатковуваної бази й виведення прибутку з-під оподаткування» (Base Erosion and Profit Shifting - BEPS). Цей документ спрямовані на те, щоб з одного боку, дати країнам інструменти для оподаткування прибутку корпорацій за місцем його виникнення, тобто створення вартості, а з іншого - більшу визначеність бізнесу щодо застосування та дотримання стандартизованих міжнародних податкових правил [3, с. 54] .

3 метою переведення податкового контролю до міжнародного рівня ефективності, Україна бере участь у Глобальному форумі з прозорості та обміну інформацією для податкових цілей та підписує Меморандум про взаєморозуміння щодо зміцнення співпраці між OECP і Україною. Також приймається низка законів, спрямованих на вдосконалення національного законодавства, серед яких Закон України № 72-VIII «Про внесення змін до Податкового кодексу України щодо удосконалення податкового контролю за трансфертним ціноутворенням» та Закон України № 1701-VII «Про внесення змін до деяких законодавчих актів України щодо визначення кінцевих вигодоодержувачів юридичних осіб та публічних діячів». Ці закони спрямованні на усунення суперечностей в законодавстві, а також вдосконалення податкового контролю та підвищення прозорості інформації про структуру власності суб'єктів господарювання [7,9].

Одним 3 наступних кроків Україн стає приєднання до Плану BEPS. 2 листопада 2016 року Міністр фінансів України передав відповідного офіційного листа генеральному секретарю ОЕСР. Передбачалось, що це фінальна процедура, яка дозволить Україні набути офіційного членства в BEPS вже з 1 січня 2017 року [1]. В подальшому Україна повинна була реалізувати Мінімальний стандарт Плану дій BEPS, тобто чотири кроки $з$ встановлених п'ятнадцяти. Стандарт включає в себе такі пункти:

- боротьба з офшорними зонами, тобто спеціальними режимами оподаткування у певних юрисдикціях, що шкодять іншим юрисдикціям;

- удосконалення чинних угод про уникнення подвійного оподаткування шляхом включення до них запропонованих правил запобігання зловживанню угодою;

- удосконалення чинних національних правових норм стосовно документації 3 трансфертного ціноутворення та майбутнього обміну інформацією;

- удосконалення чинних угод про уникнення подвійного оподаткування шляхом підвищення ефективності механізмів вирішення спорів.

Для виконання пунктів Стандарту, що стосуються «удосконалення чинних угод», в липні 2018 року Україною підписана Багатостороння конвенція щодо виконання заходів, що відносяться до податкових угод, з метою протидії розмивання податкової бази, також відома як «MLI BEPS». Зазначена Конвенція дає змогу одночасно внести зміни до 


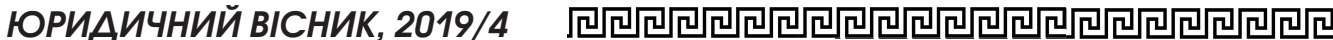

всі угод, що стосувались регулювання протидії подвійному оподаткуванню, які були підписані країнами-членами раніше.

Закон України «Про ратифікацію Багатосторонньої конвенції про виконання заходів, які стосуються угод про оподаткування, з метою протидії розмиванню бази оподаткування та виведенню прибутку з під оподаткування» був прийняти Верховною радою Україн 28.02 .2019 р. та набув чинності 02.04.2019 р. В серпні цього ж року Україна передала ратифікаційну грамоту на зберігання депозитарію ОЕСР. Сама Конвенція для України набрала чинності 01.12.2019 року.

Щодо подальших дій України з вдосконалення податкового контролю, варто згадати про прийнятий за основу 03.12.2019 року проект Закону «Про внесення змін до Податкового кодексу України щодо вдосконалення адміністрування податків, усунення технічних та логічних неузгодженостей у податковому законодавстві». Законопроект розроблений $з$ метою запровадження міжнародних стандартів податкового контролю для всіх учасників міжнародної торгівлі та імплементація норм, передбачених Планом, реформування інституту фінансової відповідальності та удосконалення процедури адміністрування податків та зборів [6].

Зі змін запропонованих в проекті Закону можна виділити декілька особливо цікавих:

- запровадження трирівневої структури документації для міжнародних груп компаній, яка включає в себе документацію 3 трансфертного ціноутворення (локальний файл), глобальну документацію (майстер-файл) та звіт у розрізі країн (country-by-country reporting);

- запровадження в межах Податкового кодексу України принципу винної відповідальності платника податку за податкові правопорушення;

- визначення вимог щодо вмотивованості рішення контролюючих органів про накладення штрафів, а саме передбачається, в якості обов'язкових, наяв- ність описової та мотивувальної частин податкового повідомлення-рішення;

- закріплення переліку податкових правопорушень контролюючих органів, які серед іншого, будуть включати недотримання ними процедури реєстрації платників податку чи порушення у сфері відшкодування податку на додану вартість;

- закріплення матеріальної відповідальності органу за неправомірні діяння його посадових осіб та безвинну відповідальність контролюючих органів;

- запровадження колегіального розгляду матеріалів податкової перевірки комісією 3 питань розгляду заперечень та встановлення чіткого переліку обставин, які підлягають встановленню під час розгляду матеріалів [8].

Звичайно розвиток України, як держави суб'єкта, в систему міжнародного податкового контролю не закінчуються приєднанням до реалізації плану BEPS. Здійснюються активні діï 3 впровадження міжнародних стандартів в сфері обміну податковою інформацією.

Так, 7 лютого 2017 року, було підписано міжурядову угоду щодо підвищення рівню дотримання міжнародного податкового законодавства та виконання положень Закону США «Про податкові вимоги до іноземних рахунків». Угода являє собою текст з 10 статей, що встановлюють: визначення основних понять; зобов'язання отримувати та здійснювати обмін інформацією стосовно американських підзвітних рахунків; час та спосіб здійснення обміну інформацією; застосування Закону FATCA до фінансових установ України; співпраця у виконанні вимог та примусове виконання; взаємні зобов'язання щодо збільшення ефективності обміну інформацією та прозорості; послідовність у застосуванні FATCA до партнерських юрисдикцій [10]. Угода була ратифікована Верховною Радою України 29 жовтня 2019 року.

Ще один пункт в процесі наближення до міжнародних стандартів обміну інформацією в сфері податкового 
контролю є приєднання України до системи CRS розробленої OECР. Стандарт міжнародного автоматичного обміну інформацією про фінансові рахунки в податкових цілях (CRS) являє собою модельний документ, який передбачає щорічний автоматичний обмін інформацією між державами, які прийняли його для використання. У документі описано, яка саме інформація підлягає міжнародному обміну, вказані фінансові організаціі, які повинні збирати i надавати податково-значущі відомості владі для подальшого міжнародного обміну, описані типи рахунків і податкових резидентів, за якими повинна збиратися і надаватися така інформація, а також уніфіковані методи перевірки благонадійності клієнтів при відкритті рахунків [2]. Обмін податковою інформацією за вказаними стандартами проводиться з 2017 року. Планувалося, що Україна вперше приєднається до обміну в 2020 році, а предметом обміну стануть данні за результатами 2019 року. Проте врегулювання даного питання залишається все ще юридично не закріпленим в національному законодавстві.

Отже, Україна робить впевненні кроки на шляху до удосконалення податкового контролю, беручи активну участь в реалізації міжнародних проектів 3 протидіiі негативним явищам в сфері оподаткування. По при це, податкове законодавство все ще має прогалини, які потребують уваги законотворчих органів, зокрема це стосується питання обміну податковою інформацією 3 країнами-партнерами з застосуванням стандартів CRS.

Стаття присвячена вивченню процесу впровадження міннародних стандартів податкового контролю в національну правову систему. Податковий контроль є важливою ланкою державного контролю, яка при ефективному правовому регулюванні та успішній організації здатна наповнювати бюджет краіни необхідними їи коштами для забезпечення стабільного сочіального та економічного розвиту держави. Перепоною на шляху досягнення поставленої иілі є проблема ухилення від сплати податків, в тому числі з використанням прогалин у законодавстві та міжнародних угодах $i$ недосконалостей правового регулювання податкового контролю. Ухилення від сплати податків давно стало масовим явищем, яке негативно впливає на економічний стан країни, незалежно від рівня ї̈ розвитку. Задля протидіï даній проблемі розвинуті країни беруть активну участь у розробиі та впровадженні дієвих способів здійснення податкового контролю. В умовах сучасних реформаційних проц̧есів та з огляду на розвиток української економіки, постає актуальним питання співпраці України з іншими країнами в сфері контролю за оподаткуванням та імплементаціі міжнародних стандартів податкового контролю у вітчизняне законодавство.

Метою статті $є$ теоретичний аналіз розвитку нормативно-правового забезпечення впровадження в Україні міжнародних стандартів податкового контролю.

У статті розглянуто вплив глобальних негативних явищ, таких як агресивне податкове планування, на міннародні відносини в сфері оподаткування. Проаналізовано найбільш яскраві тендениії розвитку норм міжнародного податкового контролю та їх вплив на реформування нормативно-правового регулювання податкового контролю в Україні. Досліджено кроки держави з юридичного закріплення міжнародних стандартів податкового контролю в національному законодавстві. Незважаючи на, в загальному, досить позитивну динаміку з впровадження нових стандартів виявлено юридичну прогалину, щз стосується правового регулювання процесу міжнародного обміну інформацією в податкових цілях. 


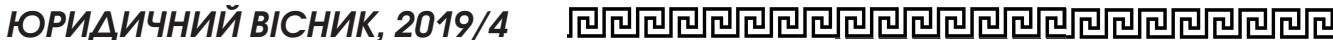

Ключові слова: податковий контроль, протидія розмиванню податкової бази, автоматичний обмін податковою інформацією, План BEPS.

Podolskaya A. IMPLEMENTATION OF INTERNATIONAL TAX CONTROL STANDARDS IN UKRAINIAN LEGISLATION

The article is devoted to the study of the process of introducing international tax control standards into the national legal system. Tax control is an important element of state control, which, with effective legal regulation and successful organization, is able to fill the country's budget with the funds it needs to ensure stable social and economic development of the state. The obstacle to achieving this goal is the problem of tax evasion, including the use of loopholes in legislation and international agreements and the imperfections of legal regulation of tax control. Tax evasion has long become a mass phenomenon, which negatively affects the economic state of a country, regardless of its level of development. For the sake of counteracting this problem, developed countries are actively involved in the development and implementation of effective ways of exercising tax control. In the context of modern reform processes and in view of the development of the Ukrainian economy, the question of cooperation of Ukraine with other countries in the sphere of tax control and implementation of international standards of tax control into domestic legislation becomes urgent.

The purpose of the article is a theoretical analysis of the development of regulatory support for the implementation of international tax control standards in Ukraine.

The article deals with the impact of global negative phenomena, such as aggressive tax planning, on international taxation relations. The most prominent tendencies of the development of the international tax control norms and their influence on the reform of the legal regulation of the tax control in Ukraine are analyzed. The steps of the state to legally enforce international tax control standards to national legislation were investigated. Despite the generally positive dynamics in implementing the new standards of identification, there is a legal gap as regards the legal regulation of the international exchange of information for tax purposes.

Key words: tax control, anti-erosion of the tax base, automatic exchange of tax information, BEPS Plan.

\section{Література}

1.1 січня Україна приєднається до Плану BEPS по боротьбі з ухилянням від оподаткування. Урядовий порmaл 23.11.2016 p., URL: https: / / wшw.kmu. gov.ua / news / 249514846

2. Standard for Automatic Exchange of Financial Account Information in Tax Matters URL: http: / / www.oecd.org / ctp/exchangeof-tax-information / standard-for-automaticexchange-of-financial-account-informationfor-tax-matters-9789264216525-en.htm

3. Андреюк Н. В. Оподаткування корпорацій в контексті приєднання україни до плану BEPS: вектори ймовірних змін. Теоретичні та прикладні питання економіки, 2016. №1, C. 52-58.

4. Боксер I. Ратифікаиія MLI-конвенцї: наслідки для України, Юридична Газета, 2019, №33-34 (687-688), URL: http: / / yur-gazeta.com / publications / practice / podatkova-praktika / ratifikaciyamlikonvenciyi-naslidki-dlya-ukrayini.html

5. Латковська Т.А. Принщии недопустимості подвійного оподаткування. International scientific and practical conference "Legal practice in EU countries and Ukraine at the modern stage». Arad, Romania : «Izdeonieciba Baltija Publishing», 25-26 January, 2019. P. 376-380. 5.

6. Пояснююча зписка до проекту Закону 30.08.2019 № 1210 «Про внесення змін до Податкового кодексу України щзодо вдосконалення адміністрування податків, усунення технічних та логічних неузгодженостей у податковому законодавстві» URL: http: / / w1.c1.rada.gov.ua/pls / zweb2/ webproc4_1?pf3511=66520

7. Про внесення змін до деяких законодавчих актів України щодо визначення 


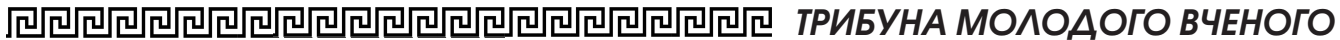

кіниевих вигодоодержувачів юридичних осіб та публічних діячів. Закон України № 1701-VII URL: http: / / zakon5.rada.gov. ua/laws / show / 1701-18

8. Про внесення змін до Податкового кодексу України щооо вдосконалення адміністрування податків, усунення технічних та логічних неузгодженостей у податковому законодавстві. Проект Закону 30.08.2019 № 1210 URL: http://search. ligazakon.ua/l_doc2.nsf/link1/JI00230A. html
9. Про внесення змін до Податкового кодексу Украӥни шодо удосконалення податкового контролю за трансфертним ијіноутворенням. URL: http: / / zakon3.rada. gov.ua/laws / show / 72-19

10. Угода між Урядом України та Урядом Сполучених Штатів Америки для поліпшення виконання податкових правил й застосування положень Закону США "Про податкові вимоги до іноземних рахунків" (FATCA), ратифіковано Законом № 229IX віо 29.10.2019, URL: https: / / zakon.rada. gov.ua / laws / show /840_005-17\#n2 